\title{
Growth And Implications Of Social E-Commerce And Group Buying Daily Deal Sites: The Case Of Groupon And Livingsocial
}

Suzaan Hughes, Monash University, South Africa Chantal Beukes, Monash University, South Africa

\begin{abstract}
E-commerce has changed the nature of the value propositions that companies now offer to their customers. The convergence of content sites and social networks has resulted in emerging ecommerce business models. The group buying/local daily deals e-commerce platform represents the collective bargaining power that individuals can leverage to obtain daily deals on local products, services and "experiences". These local discounted deals are distributed via e-mail and the websites of companies like Groupon and LivingSocial that have established themselves as the sector leaders. The convergence of traditional and electronic business models, as well as traditional and new business practices, are changing the face of global business as we know it. In this study, the authors critically reflect on the strategic management implications of the convergence of content, community and commerce in the form of social e-commerce and daily deal sites. The authors consider the implications of the rapid growth experienced by daily deal social group buying sites, in terms of strategy, and question its long-term value-creation. Future investors are urged to consider the long-term value-creation and not merely the short-term payoff of these sites. Merchants are urged to consider the practical implications of offering coupons on these sites for the day-to-day operation of their businesses.
\end{abstract}

Keywords: Daily Deal Sites; Group Buying; Social e-Commerce; Groupon; Livingsocial

\section{INTRODUCTION}

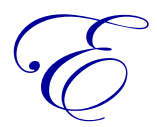

-commerce represents a paradigm shift - "It is a 'disruptive' innovation that is radically changing the traditional way of doing business" (Lee, 2001, p. 349). E-commerce has changed the nature of the value propositions that companies now offer to their customers. The convergence of content sites and social networks has resulted in emerging e-commerce business models. The group buying/local daily deals e-commerce platform represents the collective bargaining power that individuals can leverage to obtain daily deals on local products, services and "experiences" (Gridley \& Company, 2011, p. 35). These local discounted deals are distributed via e-mail and the websites of companies like Groupon and LivingSocial that have established themselves as the sector leaders (Deal-umpire.com, 2011; Gridley \& Company, 2011, p. 36; Saporito, 2011, p. 42). ${ }^{1}$ Due to the critical mass of consumers needed to activate the deal, users are prompted to act as agents of viral marketing by informing other people likely to be interested, using various social media. Social media is thus driving consumption of local product and service offerings (Gridley \& Company, 2011, p. 9).

E-commerce is growing at five times the rate of traditional retail channels. New avenues of e-commerce, such as daily deals offered by companies like Groupon and LivingSocial, have boosted the sector's momentum since 2010 (Gridley \& Company, 2011, p. 6). The group buying industry has an estimated value of approximately US $\$ 2.7$

\footnotetext{
${ }^{1}$ Also see Appendix A

(C) 2012 The Clute Institute http://www.cluteinstitute.com/
} 
billion (Kessler, 2011). This translates into roughly 138\% growth in 2011 alone (Kessler, 2011). The rapid growth that both these companies have experienced in less than five years since their launch dates and the unparalleled pace of adoption and frequency of utilization by consumers merits investigation of this emerging business model.

Groupon has taken the established and unquestioned marketing tactic of utilizing coupons and brought it swiftly into the 21 st century. LivingSocial has brought social interaction and life experiences online. In addition, these technology platforms provide local businesses with access to their closest customers. Customers have become co-creators of value. This is a typical example of the experience economy described by Pine and Gilmore (1998). The emergence of daily deal social group buying sites is interesting from both a strategy perspective, as well as a development and growth perspective, as it challenges our traditional understanding of what it takes to build a business that is profitable.

\section{Research Purpose}

The convergence of traditional and electronic business models, as well as traditional and new business practices, are changing the face of global business as we know it. Electronic business models provide a particular opportunity for content, community and commerce to converge. At the intersection of these previously unrelated ideas, we find the spawning grounds of social e-commerce. Thus, this study aims to provide insight and critical reflections on the strategic management implications of this convergence. In this case study, the authors consider the implications of the rapid growth experienced by daily deal social group buying sites, in terms of strategy, and question its long-term value creation.

\section{RESEARCH DESIGN \& METHODOLOGY}

A case study research methodology was applied in this paper. Case studies are usually qualitative in nature (De Vos, Strydom, Fouché \& Delport, 2009, p. 272; Eriksson \& Kovalainen, 2008, p. 116; Leedy \& Ormrod, 2010, p. 137; Merriam, 2009, p. 39) and are aimed at discovering meaning and gaining heuristic understanding (Eriksson \& Kovalainen, 2008, p. 117; Merriam, 2009, p. 39). Case study research allows the researcher to present complex and hard-to-grasp business issues in an accessible, vivid, personal and simple format (Eriksson \& Kovalainen, 2008, p. 116), with the end-product being richly descriptive (Merriam, 2009, p. 39, 43; Tellis, 1997). This particular study focused on two leading players in the group buying and daily deal social e-commerce arena; namely, Groupon and LivingSocial. The particularistic nature (Merriam, 2009, p. 43) of case study research presents a major limitation to this type of research strategy in that the findings might have limited generalisability (Leedy \& Ormrod, 2010, p. 137). However, the specificity of focus makes it a good design for addressing practical problems or issues such as questions or puzzling occurrences arising from everyday situations (Merriam, 2009, p. 43).

\section{DISCUSSION}

To understand the phenomenon of daily deal social group buying sites, an overview of the evolution of the e-commerce landscape is necessary as it will provide greater clarity on the development of social group buying. Figure 1 illustrates the evolution of social e-commerce. This evolution is briefly discussed below. Information was obtained from the comprehensive research report and industry overview published by Gridley and Company (2011).

The Internet was launched in 1994. Between 1994 and 1997, companies started going online. At this stage, going online meant having a presence on the Internet. Most companies still utilized the traditional bricks-and-mortar model to conduct their core business. However, with the rapid growth and interest in the Internet, some companies, like Dell, realized that it needed to capitalize on this opportunity for reconfiguring its business model to take direct selling online. It was during this early phase of emerging e-commerce that Dell made its first million dollars in online sales. 


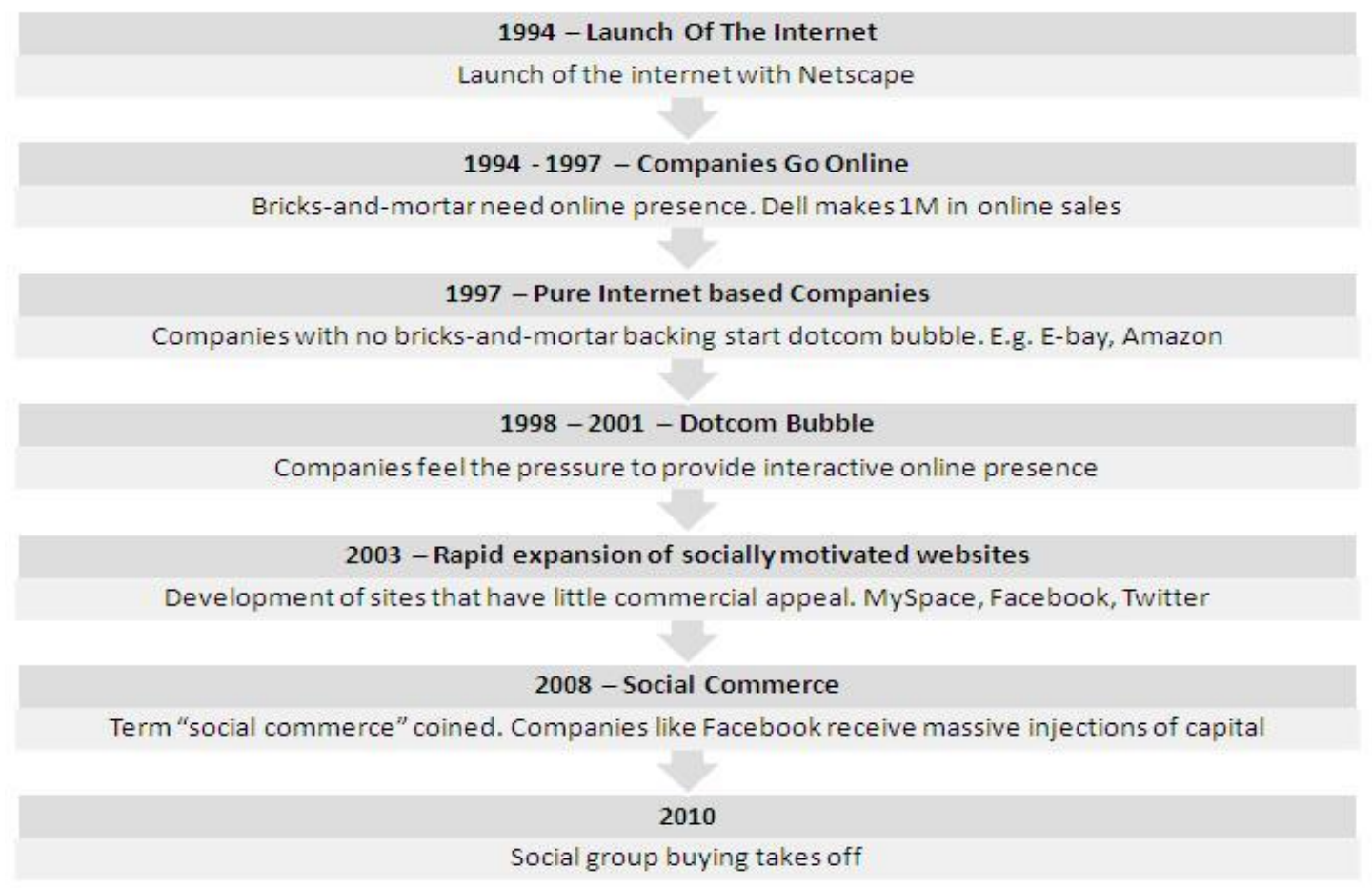

Figure 1: The Evolution of Social e-commerce Source: Adapted from Gridley and Company, 2011

In the late 1990's and early 2000's, companies started moving away from the traditional bricks-and-mortar model and became entirely Internet-based - companies like E-bay and Amazon. The exponential growth achieved and the ease with which online companies could infiltrate different consumer markets in different countries led to increased pressure for companies to have an active online presence. Investors saw in the Internet what they thought, at the time, to be a "business model" that could not fail instead of realizing the value of the Internet as a business model enabler. Stock prices soared and this led to the Dotcom Bubble growing between 1998 and 2001.

The burst of the Dotcom Bubble in 2002 saw an initial retraction in the volume of online companies. However, it did not stem the growing tide of online communities. With most people weary after the burst of the Dotcom Bubble, consumers still wanted a way to interact online. This saw the rise of sites like MySpace, Twitter and Facebook. These sites initially had little commercial appeal for the owners of these online companies. People could form online communities and share thoughts, ideas and experiences. It was a simple and easy way for people in different parts of the world to establish or maintain friendships, to network and to share information.

With the potential for these social websites to attract venture capital, the time was ripe for social ecommerce to emerge. The term social e-commerce was coined in 2008 when companies, like Facebook, started to receive massive capital injections. It did not take long for others to realize the massive potential buying power of online social groups and companies, focused on capitalizing on this phenomenon, start to emerge. One of the first companies of this nature to arise was LivingSocial. LivingSocial (originally known as Hungry Machine; trading as LivingSocial since 2009) was launched in 2007 as a group buying social commerce site (CrunchBase, 2011; Frean, 2010). It offers customers "handpicked experiences that can be shared with friends" (LivingSocial.com, 2011).

LivingSocial claims that it inspires members to share and enjoy the best of their neighborhoods by providing them with a platform to connect with handpicked experiences in and around their neighborhoods (LivingSocial.com, 2012). In December 2010, LivingSocial secured US\$175 million investment from Amazon and an additional US\$8 million investment from Lightspeed Venture Partners (LivingSocial.com, 2012). More than 60 
million users and their acquaintances can save as much as 90 percent per day on everything from restaurant meals to hotels and sporting events (CrunchBase, 2011; LivingSocial, 2012; Gridley \& Company, 2011). LivingSocial is valued at $\$ 5$ billion with estimated revenue of $\$ 50$ million in February 2011 (Arrington, 2011). Widely referred to as Groupon's closest competitor in social commerce, LivingSocial receives about twenty percent of the overall traffic from daily deal-seekers (MacMillan \& Galante, 2011; Saint, 2011; Wonham, 2010).

Groupon, the fastest growing and biggest daily deal social group buying site and LivingSocial's biggest competitor, was launched in November 2008. It features a daily deal on "the best stuff to do, see and buy in more than 500 markets and 44 countries" (Groupon, 2011). The response to the website was viral, starting with merchants in Chicago and neighboring cities lining up. The growth spurt overwhelmed some early adopters of this technology. No start-up has grown as fast. Within a year, Groupon had one million adherents and today it has 143 million subscribers around the world (Privco, 2012; Stone \& MacMillan, 2011). It went from zero to US\$500 million in sales in the first 18 months (Saporito, 2011, p. 40). Table 1 provides a breakdown of the growth and development these two companies have experienced since their launch dates.

Table 1: Facts and Figures - Comparison between LivingSocial and Groupon

\begin{tabular}{|c|c|c|}
\hline Launch date & $\begin{array}{l}2007 \text { (originally known as Hungry } \\
\text { Machine; trading as LivingSocial since } \\
2009)(5 ; 8)\end{array}$ & $2008(7)$ \\
\hline Description & $\begin{array}{l}\text { "Handpicked experiences that can be } \\
\text { shared with friends" (8) }\end{array}$ & "Daily deals on things to do, see \& eat" (7) \\
\hline How are deals advertised? & $\begin{array}{l}\text { Web and e-mail (4); via mobile (iPhone } \\
\text { application) since December } 2009 \text { (8) }\end{array}$ & $\begin{array}{l}\text { Web, e-mail and mobile (iPhone, Android } \\
\text { and Blackberry) (4) }\end{array}$ \\
\hline Venture capital profile & $\begin{array}{l}\text { Total raised: } \$ 232 \text { million in venture } \\
\text { capital (11). } \\
\$ 175 \text { million from Amazon and } \$ 8 \\
\text { million from Lightspeed Venture } \\
\text { Partners (December 2010) }(6 ; 8)\end{array}$ & $\begin{array}{l}\text { Total raised: } \$ 1.4 \text { billion in venture capital } \\
(10 ; 11) \\
\$ 6 \text { billion offer by Google - rejected } \\
\text { (December 2010) (6) }\end{array}$ \\
\hline Number of users & 60 million worldwide $(3 ; 6)$ & 143 million worldwide $(10 ; 12)$ \\
\hline Number of markets (i.e. cities) & $647(8)$ & 565 and growing (4) \\
\hline Countries & $\begin{array}{l}\text { Present in } 21 \text { countries and on six of the } \\
\text { seven continents }(8)^{2}\end{array}$ & $\begin{array}{l}\text { Present in } 44 \text { countries and on six of the } \\
\text { seven continents }(7)^{3}\end{array}$ \\
\hline Revenue for 2011 & $\begin{array}{l}\$ 245 \text { million (net loss of } \$ 558 \text { million) } \\
(9)\end{array}$ & $\$ 1.6$ billion (net loss of $\$ 275.1$ million) (10) \\
\hline Valued at & $\begin{array}{l}\$ 5 \text { billion - valued at eighteen times its } \\
\text { revenue (9) }\end{array}$ & $\begin{array}{l}\$ 12.7 \text { billion (post IPO) - valued at ten time } \\
\text { its revenue }(9 ; 10)\end{array}$ \\
\hline Most successful deal & $\begin{array}{l}\$ 20 \text { Amazon gift card for } \$ 10=1.5 \\
\text { million deals and } \$ 14 \text { million in sales }(1 ; \\
6)\end{array}$ & $\begin{array}{l}\$ 50 \text { of GAP clothing for } \$ 25=440,000 \\
\text { deals and } \$ 11 \text { million in sales }(1 ; 2)\end{array}$ \\
\hline
\end{tabular}

${ }^{2}$ Also see Appendix B

${ }^{3}$ Also see Appendix C 
Table 1: Continued

\begin{tabular}{|l|l|l|}
\hline Mergers and acquisitions & $\begin{array}{l}\text { Bought } 4 \text { companies in US and 7 } \\
\text { internationally. Has a presence in 21 } \\
\text { countries, including Australia, Spain, }\end{array}$ & $\begin{array}{l}\text { Bought 23 companies locally and } \\
\text { internationally through mergers, acquisitions } \\
\text { and joint ventures (10). Has a presence in }\end{array}$ \\
Italy, Portugal, Argentina, Mexico, & $\begin{array}{l}\text { inter alia South Africa, US, Hong Kong, } \\
\text { Chile, India, Malaysia, Israel, Russia and }\end{array}$ \\
& $\begin{array}{l}\text { France, Thailand, The Philippines, } \\
\text { Indonesia, South Korea and Malaysia; on } \\
6 \text { of the } 7 \text { continents }(8)^{4}\end{array}$ & $\begin{array}{l}\text { Germany }(6) \text { with a presence on } 6 \text { of the } 7 \\
\text { continents }(10)^{5}\end{array}$ \\
\hline Number of employees & $\begin{array}{l}4900(8)-\text { productivity per employee }= \\
\pm U S \$ 5000\end{array}$ & $\begin{array}{l}1000(7 ; 10)-\text { productivity per employee } \\
= \pm U S \$ 155000\end{array}$ \\
\hline
\end{tabular}

*Sources used to compile table:

1) Bulik, B. S. (2011). Bad news for small-towners seeking daily group deals: Vendor abundance has Groupon, LivingSocial skewing urban - for now. Advertising Age, 82(19), 5.

2) Butler, P. (2011). Deconstructing the Groupon phenomenon: Which Groupon promotions get results. Harvard Business Review. July-August, 32-33.

3) CrunchBase. (2011). LivingSocial profile. Accessed on 2011-05-19 from: http://www.crunchbase.com/company/livingsocial\#.

4) Eldekki, R. (2011). Infographic: An analysis of Groupon, LivingSocial, FB Deals and Google offers. Blog accessed on $2012-$ 04-02 from: http://blog.hudsonhorizons.com/Article/Infographic-Groupon-Living-Social-FB-Deals--Google-Offers.htm.

5) Frean, A. (2010). Team spirit turned a start-up into a success story: Global Issues in Context, The Times, December. London: Cengage Learning. Accessed on 2011-05-19 from: http://find.galegroup.com/gic/infomark.do?\&contentSet=IAC-

Documents\&idigest=bfe82995b3da27d6931507922b243856\&type=retrieve\&tabID=T004\&prodId=GIC\&docId=CJ2435324 $04 \&$ source $=$ gale $\&$ userGroupName $=$ monashs \&version $=1.0$.

6) Gridley \& Company. (2011). Billion dollar babies: Trends and opportunities in the new e-commerce world. Comprehensive Industry Overview, April. Accessed on 2011-05-17 from: www.gridleyco.com.

7) Groupon. (2011). Groupon: Collective buying power - About us. Accessed on 2011-05-15 from: http://www.groupon.com/about.

8) LivingSocial.com. (2012). A brief company timeline. Accessed on 2012-04-02 from: http://corporate.livingsocial.com/ourhistoryoverview/a-brief-company-timeline/2009.

9) McHugh, M. (2012). Groupon: New numbers suggest its shares are a deal compared to LivingSocial. Y-Charts. Accessed on 2012-04-02 from:

http://ycharts.com/analysis/story/groupon_new_numbers_suggest_its_shares_are_a_deal_compared_to_livingsocial.

10) Privco. (2012). Groupon Inc. Report on Groupon compiled by Privco. March 2012. Accessed on 2012-04-02 from: http://www.privco.com/private-company/groupon-inc.

11) Sherman, E. (2011). Groupon and LivingSocial: The next bubble waiting to pop [Update]. CBS Interactive Inc. Accessed: 2012-04-02. From: http://www.cbsnews.com/8301-505124_162-43449502/groupon-and-livingsocial-the-next-bubblewaiting-to-pop-update/.

12) Stone, B. \& MacMillan, D. (2011). Are four words worth $\$ 25$ billion for Groupon? Business Week, March. Accessed on 2011 05-15 from: http://www.businessweek.com/magazine/content/11_13/b4221070014682.

\section{FINDINGS AND MANAGERIAL IMPLICATIONS}

A key criterion of sustainable competitive advantage is inimitability (Porter, 1996). This is being challenged for both Groupon and LivingSocial as major industry players, such as Google and Facebook, are already copying their user interface. In addition, while both companies have posted impressive growth records and boast large cash injections from venture capitalists, the long-term success and relevance of their concept is yet to be proven. A major challenge in the internationalization of both these businesses, as they rush to grab more markets, is the accessibility of the Internet in developing markets, as well as the technological sophistication of customers in these markets. This shortcoming could be mitigated by the development of market relevant mobile applications.

In 2009, LivingSocial released its first LivingSocial iPhone application (LivingSocial.com, 2012). Groupon has an iPhone, Android and Blackberry application. Thus, these companies realize the value a mobile platform holds for the expansion of the business. However, one wonders if their mobile presence simply emerged as a result of the drive to incorporate as many platforms as possible, or whether it was part of a carefully executed localization

${ }^{4}$ See Appendix B

${ }^{5}$ Seep Appendix C

(C) 2012 The Clute Institute http://www.cluteinstitute.com/ 
strategy. An intentional strategy would involve consideration of limitations and differences in markets other than the US. The mobile platform is an excellent avenue for access to one-third of the world/developing markets; however, the advertising needs to be refined for geographical and societal differences that the companies would encounter in these markets. ${ }^{6}$

The paradox of uniqueness is that every daily deals company believes it is unique. Traditional strategic management posits that one of the foundations of a sustainable competitive advantage is the uniqueness and inimitability of the company as a whole or of the way it conducts its business (Porter, 1996, p. 62). While there may be some differences between daily deal sites, it is highly unlikely that these differences translate into something that can truly be defined as unique. Living Social CEO Tim O'Shaughnessy warns against comparing them with Groupon simply because they are both e-commerce companies. According to O'Shaughnessy, LivingSocial is positioning itself to offer more than daily deals by offering merchants automated tools (such as working out the lifetime value of their customers) to help run their businesses (Schonfeld, 2012). LivingSocial also segments its website according to user experiences (LivingSocial, 2012). Daily deals are only one of the categories of experiences available to users, whereas Groupon's core business is offering daily deals. It therefore seems LivingSocial's CEO has a point in arguing that direct comparison between the two companies would result in a flawed analysis.

However, whether this attempt by LivingSocial at deliberately distinguishing themselves from Groupon could be considered strategy is still doubtful. The implementation of a successful differentiation strategy requires the lapse of sufficient time in order to measure the actual effect of the strategy on market share, revenue and profit to judge if they were above industry average. The rapid growth spurt of these daily deal sites should not be mistaken for successful strategic planning as it seems that it is more a by-product of the novelty and allure of the business model than of careful evaluation of the market and consideration of potential strengths, weaknesses, opportunities and threats. One would think that after the burst of the Dotcom Bubble, people would be hesitant to invest in a new venture so quickly if there is little evidence of its long-term value.

One of the phenomena surrounding the daily deals industry is the timeline that industry commentators use when commenting on its prospects. Groupon and LivingSocial have been hailed as industry-defining success stories within the first few months of their launch. This short-term analysis timeline creates a myopic focus on the immediate and near future without answering the question, "Is any long-term value being created for customers, merchandisers and investors?" For example, the 6\% growth of Groupon - from US\$145 million in October 2011 to US\$154 million in November 2011 (see Yipit Blog, 2011) - is due to the success of two once-off product offerings, not a long-term launch of new products.

Another industry hallmark is the pace at which its biggest players - Groupon and LivingSocial - have progressed along the growth curve. They have developed from being in the embryonic stage and building their own market share to the shakeout stage and investing in their market share at the expense of weaker competitors (Jovanovic \& MacDonald, 1994; Verreynne \& Meyer, 2010). This was manifested in a globalization strategy that saw Groupon and LivingSocial buying out their most formidable international competitors/imitators (Underwood, 2010, p. 118). The pace at which imitators have copied Groupon's business idea has been both an opportunity and a threat for the company. The threat is the ease with which copycats can imitate their "lucrative business model" (Underwood, 2010, p. 116). The opportunity is manifested in the pace at which they have globalised; as most markets had a local version of Groupon which they could buy out, often retaining the local start-up's founders as management. These founders are retained because of their ability to build relationships with local merchants as clients and to adapt to local preferences while being expected to implement best practice as defined by the Chicago head office of Groupon (Underwood, 2010, p. 118). ${ }^{7}$ Thus, Groupon has managed to effectively utilize the copycats as their platform for globalization and rapid expansion. However, this seems to be more a manifestation of serendipity and emergent strategy (Mintzberg, 1987) than of planned and intentional strategy.

\footnotetext{
${ }^{6}$ Also see Appendix D for an illustration of current mobile penetration

${ }^{7}$ Also see Appendices B and C 
Along with considerations about strategy, another pertinent question is, "Do daily deal sites actually have a viable business model?" It seems to depend on who you ask. Judging by the rapid influx of venture capital, it would appear so (Tartakoff, 2010). However, do all the investors know what they are buying into? In the world of technology, the pace of change seems to cause venture capital firms to back ideas that are still in their unproven infancy so as not to miss out on the "next big thing" (i.e., Facebook). This exuberance may be well founded, but whether there is any long-term value to be gained remains to be seen. An interesting case in point is Groupons' decision to go public. In January 2011, Groupon was exploring an initial public offering (IPO) to the value of $\$ 15$ billion. In June 2011, when filing for the IPO, they increased their estimation to $\$ 20$ billion. This increase was supported by the enthusiastic backing of the lead underwriters of the IPO - Morgan Stanley, Goldman Sachs Group Inc. and Credit Suisse. Amid scrutiny of their financials, the IPO was postponed to November 2011 and the valuation revised down to $\$ 12.7$ billion (Privco, 2012). Rumors surfaced that LivingSocial was also considering going public (McHugh, 2011). However, once they saw the scrutiny Groupon's financials were subjected to, they decided to continue trading as a private company for the time being. These events leave one wondering if the next "tech bubble" (McHugh, 2011) would be an e-commerce one.

\section{CONCLUSION AND RECOMMENDATIONS}

Perhaps potential merchants and investors should consider the following wise advice offered by Del Rey (2010, p. 104):

- $\quad$ Potential merchants should consider the profit pay-off. Offering a 50\% discount on a product or service, of which Groupon takes about half the profit, may be unaffordable for the merchant.

- Merchants should tell Groupon how many coupons they can offer. Inexperienced merchants that neglect to do this may find their business overwhelmed by more customers than they can handle.

- Personal contact details can lead to thousands of phone calls. An online reservation system linked to the merchant's website is suggested.

- Lastly, training customers to wait for discounts and only buy with coupons will erode the merchant's profitability. Thus, they should be used sparingly.

As one merchant notes, Groupon essentially makes a $50 \%$ profit margin on sending a merchant's offer to subscribers on their e-mail list (Del Rey 2010, p. 104). So, at worst, Groupon is providing merchants with "free marketing" which results in higher customer traffic. If almost none of that traffic results in return business, then the cost of offering steep discounts does not translate into higher long-term profits for the merchants who use Groupon. It is also important to note that if a merchant cannot service the clients who have bought coupons at the customary levels of the company due to the volume of customers that buy into the offer, the merchant's image may actually be damaged in the long run.

The convergence of traditional and electronic business models, as well as traditional and new business practices, are changing the face of global business as we know it. In this study, the authors critically reflected on the strategic management implications of the convergence of content, community, and commerce in the form of social e-commerce and daily deal sites. The authors considered the implications of the rapid growth experienced by daily deal social group buying sites in terms of strategy and questioned its long-term value-creation. Future investors are urged to consider the long-term value-creation and not merely the short-term payoff of these sites. Merchants are urged to consider the practical implications of offering coupons on these sites for the day-to-day operation of their businesses.

\section{AUTHOR INFORMATION}

Suzaan Hughes is a lecturer in the Department of Management within the School of Business and Economics at Monash University, South Africa. Her research interests include strategic management, management education, leadership, managerial communication, event management and coaching and mentoring. E-mail: suzaan.hughes@monash.edu. Corresponding author. 
Chantal Beukes is a lecturer in the Department of Management within the School of Business and Economics at Monash University, South Africa. Her research interests include strategic management, management education, leadership and motivation, organizational behavior, health and wellbeing and coaching and mentoring. E-mail: chantal.beukes@monash.edu

\section{REFERENCES}

1. Arrington, M. (2011). LivingSocial financials exposed: $\$ 2.9$ billion valuation, $\$ 50$ million in revenue per month. Accessed on 2011-05-19 from: http://techcrunch.com/2011/04/15/livingsocial-financials-exposed-29-billion-valuation-50-million-in-revenue-per-month/

2. Bulik, B. S. (2011). Bad news for small-towners seeking daily group deals: Vendor abundance has Groupon, LivingSocial skewing urban - for now. Advertising Age, 82(19), 5.

3. Butler, P. (2011). Deconstructing the Groupon phenomenon: Which Groupon promotions get results. Harvard Business Review. July-August, 32-33.

4. $\quad$ CrunchBase. (2011). LivingSocial Profile. Accessed on 2011-05-19 from: http://www.crunchbase.com/company/livingsocial\#.

5. Deal-umpire.com. (2011). Groupon versus LivingSocial. Accessed on 2012-04-02 from: http://dealumpire.com/blog/2011/10/13/groupon-vs-livingsocial/

6. $\quad$ Del Rey, J. (2010). The Groupon avalanche. Inc, April, 102-104.

7. De Vos, A. S., Strydom, H., Fouché, C. B. \& Delport, C. S. L. (2005). Research at Grass Roots. ( $3^{\text {rd }}$ ed.). Pretoria: Van Schaik.

8. Eldekki, R. (2011). Infographic: An analysis of Groupon, LivingSocial, FB Deals and Google offers. Blog accessed on 2012-04-02 from: http://blog.hudsonhorizons.com/Article/Infographic-Groupon-Living-SocialFB-Deals--Google-Offers.htm

9. $\quad$ Eriksson, P. \& Kovalainen, A. 2008. Qualitative Methods in Business Research. London: Sage.

10. Frean, A. (2010). Team spirit turned a start-up into a success story: Global issues in context, The Times, December. London: Cengage Learning. Accessed on 2011-05-19 from:

http://find.galegroup.com/gic/infomark.do?\&contentSet=IAC-

Documents\&idigest=bfe82995b3da27d6931507922b243856\&type=retrieve\&tabID=T004\&prodId=GIC\&d ocId=CJ243532404\&source $=$ gale \&userGroupName $=$ monashs \& version $=1.0$

11. Gridley \& Company. (2011). Billion Dollar Babies: Trends and opportunities in the new e-commerce world. Comprehensive Industry Overview, April. Accessed on 2011-05-17 from: www.gridleyco.com

12. Groupon, 2011. Groupon: Collective Buying Power - About Us. Accessed on 2011-05-15 from: http://www.groupon.com/about

13. Hough, J. Thompson, Jr. A. A., Stickland III, A. J., Gamble, J. E., Human, G., Makin, V. \& Braxton, R. (2008). Crafting and executing strategy: Text readings and cases. Berkshire, UK: McGraw-Hill Education.

14. Jones, G. R. \& Hill, C. W. L. (2010). Theory of strategic management: With cases. $\left(9^{\text {th }}\right.$ ed.). China: Cengage Learning.

15. Jovanovic, B. \& MacDonald, G. (1994). The lifecycle of a competitive industry. Journal of Political Economy, 102(2), 1-31.

16. Kessler, S. (2011). LivingSocial says it will overtake Groupon in January 2012. Accessed: 2012-04-02 from: http://mashable.com/2011/03/24/livingsocial-says-it-will-overtake-groupon-in-january-2012/

17. Lee, C. (2001). An analytical framework for evaluation e-commerce business models and strategies. Internet Research, 11(4), 349-359.

18. Leedy, P. D. \& Ormrod, J. E. (2010). Practical Research: Planning and Design. ( ${ }^{\text {th }}$ ed.). Upper Saddle River, New Jersey: Pearson.

19. Linder, J. C. \& Cantrell, S. (2000).Changing business models: Surveying the landscape. Institute for Strategic Change, Accenture.

20. LivingSocial.com. (2011). About LivingSocial. Accessed on 2011-05-16 from: http://corporate.livingsocial.com/home

21. LivingSocial.com. (2012). Who we are. Accessed on 2012-04-02 from: http://corporate.livingsocial.com/home

22. LivingSocial.com. (2012). A brief company timeline. Accessed on 2012-04-02 from: http://corporate.livingsocial.com/ourhistoryoverview/a-brief-company-timeline/2009 
23. MacMillan, D. \& Galante, J. (2011). LivingSocial is said to seek funding valuing daily-deal site at \$2 billion. Bloomberg, March. Accessed on 2011-05-17 from: http://www.bloomberg.com/news/2011-0316/livingsocial-is-said-to-seek

24. Magretta, J. (2002). Why business models matter. Harvard Business Review, 80(5), 86-92.

25. McHugh, M. (2011). Rumour: LivingSocial about to begin IPO process. Digital Trends, July. Accessed on 2012-04-03 from: http://www.digitaltrends.com/social-media/rumor-livingsocial-about-to-begin-ipoprocess/

26. McHugh, M. (2012). Groupon: New numbers suggest its shares are a deal compared to LivingSocial. $Y$ Charts. Accessed on 2012-04-02 from: http://ycharts.com/analysis/story/groupon_new_numbers_suggest_its_shares_are_a_deal_compared_to_livi $\underline{\text { ngsocial }}$

27. Merriam, S. B. (2009). Qualitative Research: A guide to design and implementation. San Francisco, California: Jossey-Bass.

28. Mintzberg, H. (1987). The strategy concept I: Five keys for strategy. California Management Review, Fall, 11-23.

29. Online Marketing Trends. (n.d.). Online marketing trends: Global tech comparison: Internet versus mobile versus social. Accessed on 2012-04-03 from: http://www.onlinemarketing-trends.com/2012/03/globaltechnology-penetration-internet.html

30. Pine II, B. J. \& Gilmore, J. H. (1998). Welcome to the experience economy. Harvard Business Review, July/August, 97-105.

31. Porter, M. E. (1996). What is strategy? Harvard Business Review, 74(6), 61-79.

32. Privco. (2012). Groupon Inc. Report on Groupon compiled by Privco. March 2012. Accessed on 2012-0402 from: http://www.privco.com/private-company/groupon-inc

33. Saint, N. (2011). LivingSocial just declared war on the daily deal aggregators. Business Insider, January. Accessed on 2011-05-17 from: http://www.businessinsider.com/livingsocial-is-cutting-out-the-daily-dealaggregators-2011-1

34. Saporito, B. E. (2011). The Groupon Clipper. Time, February, 40-42.

35. Schonfeld, E. (2012). LivingSocial CEO: Lumping us with Groupon is like lumping eBay with Amazon. Accessed: 2012-04-02 from: http://techcrunch.com/2012/01/29/livingsocial-ceo-lumping-groupon-ebayamazon/

36. Sherman, E. (2011). Groupon and LivingSocial: The next bubble waiting to pop [Update]. CBS Interactive Inc. Accessed: 2012-04-02. From: http://www.cbsnews.com/8301-505124_162-43449502/groupon-andlivingsocial-the-next-bubble-waiting-to-pop-update/

37. Slywotzky, A. J. (1996). Value migration: How to think several moves ahead of the competition. Boston, Massachusetts: Harvard Business School Press.

38. Stone, B. \& MacMillan, D. (2011). Are four words worth \$25billion for Groupon? Business Week, March. Accessed on 2011-05-15 from: http://www.businessweek.com/magazine/content/11_13/b4221070014682

39. Tartakoff, J. (2010). LivingSocial raises another $\$ 14$ million to expand group buying sites. Accessed: 201109-23 from: http://paidcontent.org/article/419-group-buying-site-livingsocial-raises-another-\$14Million-toexpand-group-buying-sites

40. Tellis, W. (1997). Introduction to case study. The Qualitative Report, 3(2), Available from: http://www.nova.edu/QR/QR3-2/tellis1.html

41. Underwood, R. (2010). Going global, Groupon versus the world. Inc, October, 116-118.

42. Verreynne, M. L. \& Meyer, D. (2010). Small business strategy and the industry life cycle. Small Business Economics, 35, 399-416.

43. Wonham, L. (2010). Cashing in on daily deals: Groupon, LivingSocial, Tipper. Website Magazine. September. Accessed on 2011-05-17 from: http://www.websitemagazine.com/content/blogs/posts/archive/2010/09/15/cashing-in-on-the-daily-dealscraze.aspx

44. Yipit Blog. (2011). Raw daily deal data. Accessed 2012-04-01 from: http://yipit.com/data/raw/ 


\section{APPENDIX A}

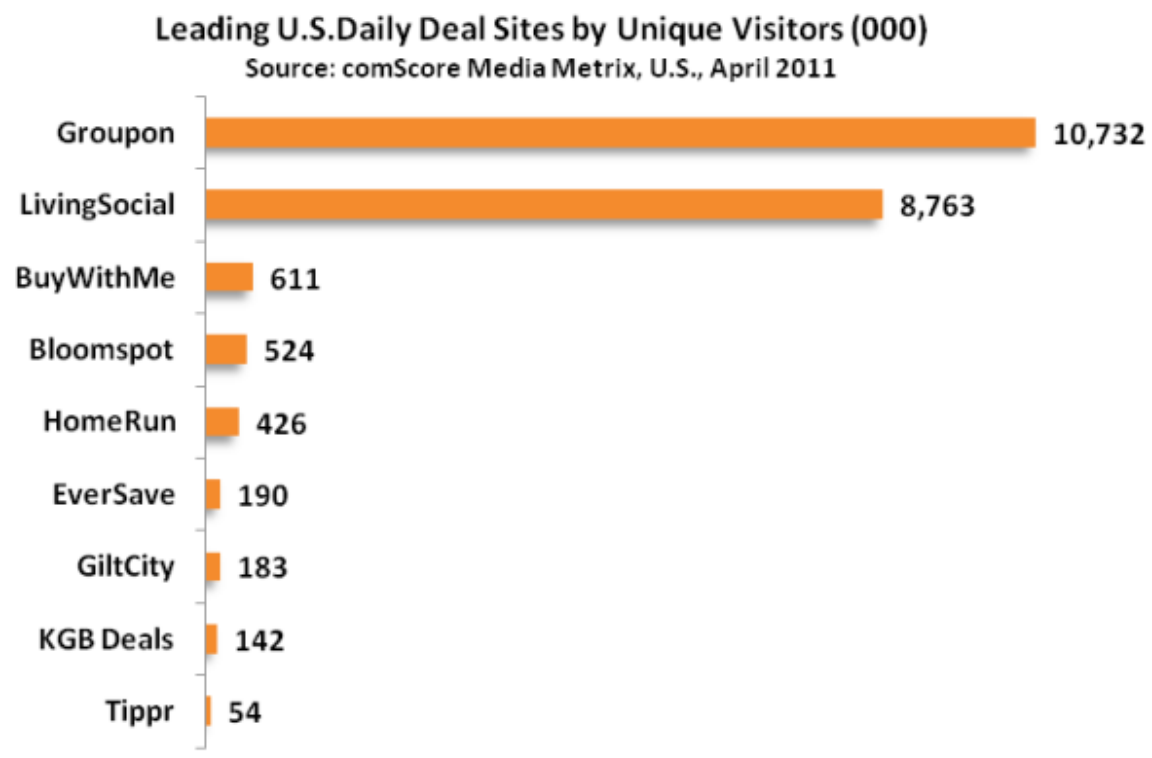

Source: Deal-umpire.com, 2011 (http://deal-umpire.com/blog/2011/10/13/groupon-vs-livingsocial/) 


\section{APPENDIX B}

LivingSocial Branches Around The World

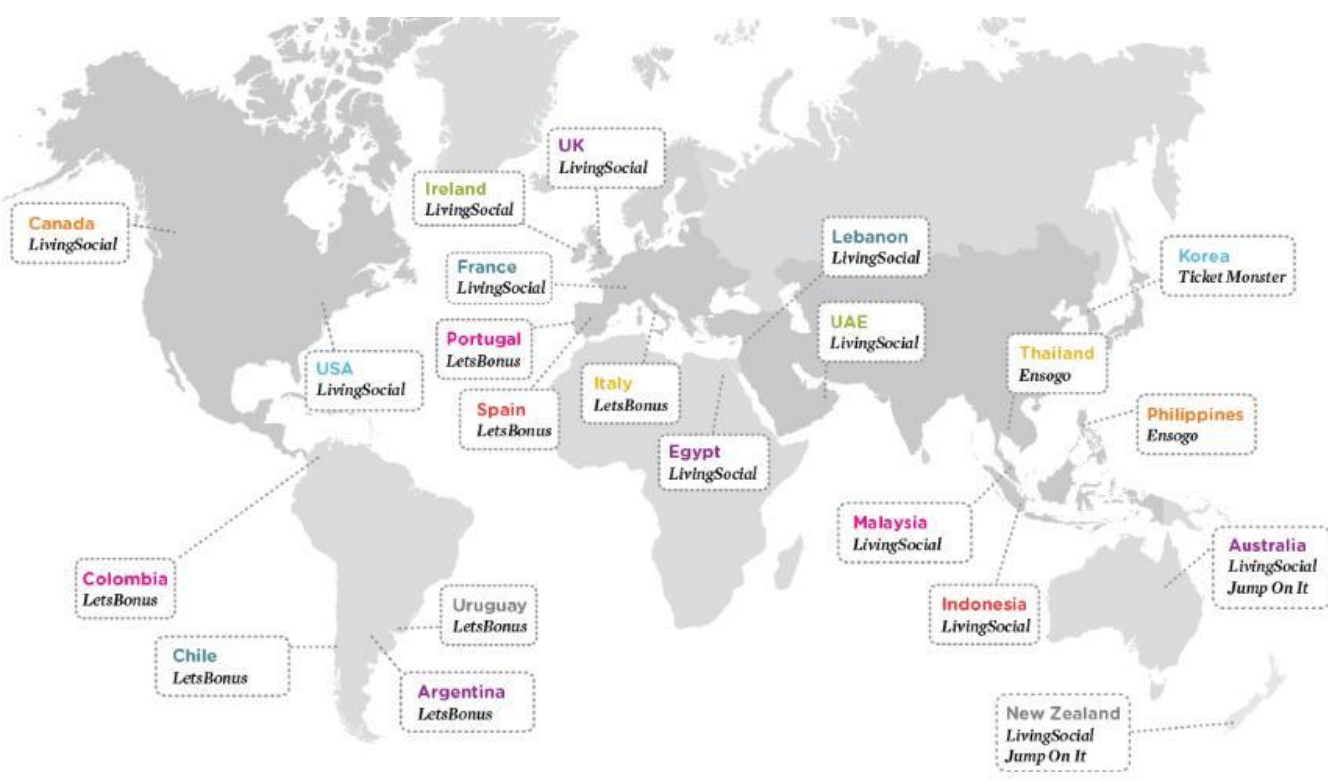

Source: LivingSocial, 2012 


\section{APPENDIX C}

\section{Groupon Globalisation by Corporate Buy-out}

\section{All Over The Map}

In the two years since its founding, Groupon has seen its business model copied by companies in about 50 countries (we marked them with red pins). But Groupon has a new strategy to broaden its global dominion (shown on the green areas of the map).

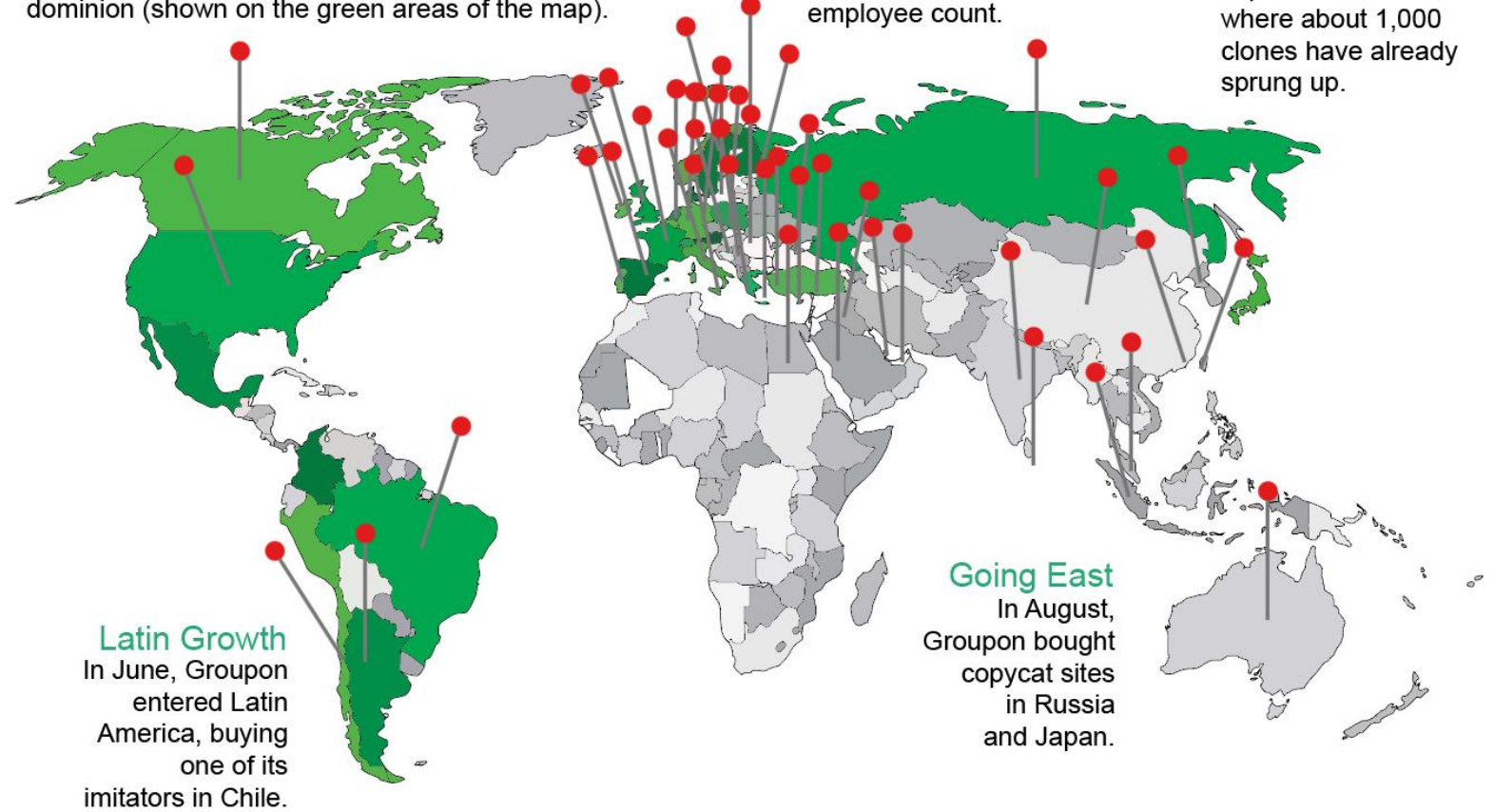

Source: Underwood, 2010, p. 116 


\section{APPENDIX D}

Mobile Penetration of Online Marketing Trends

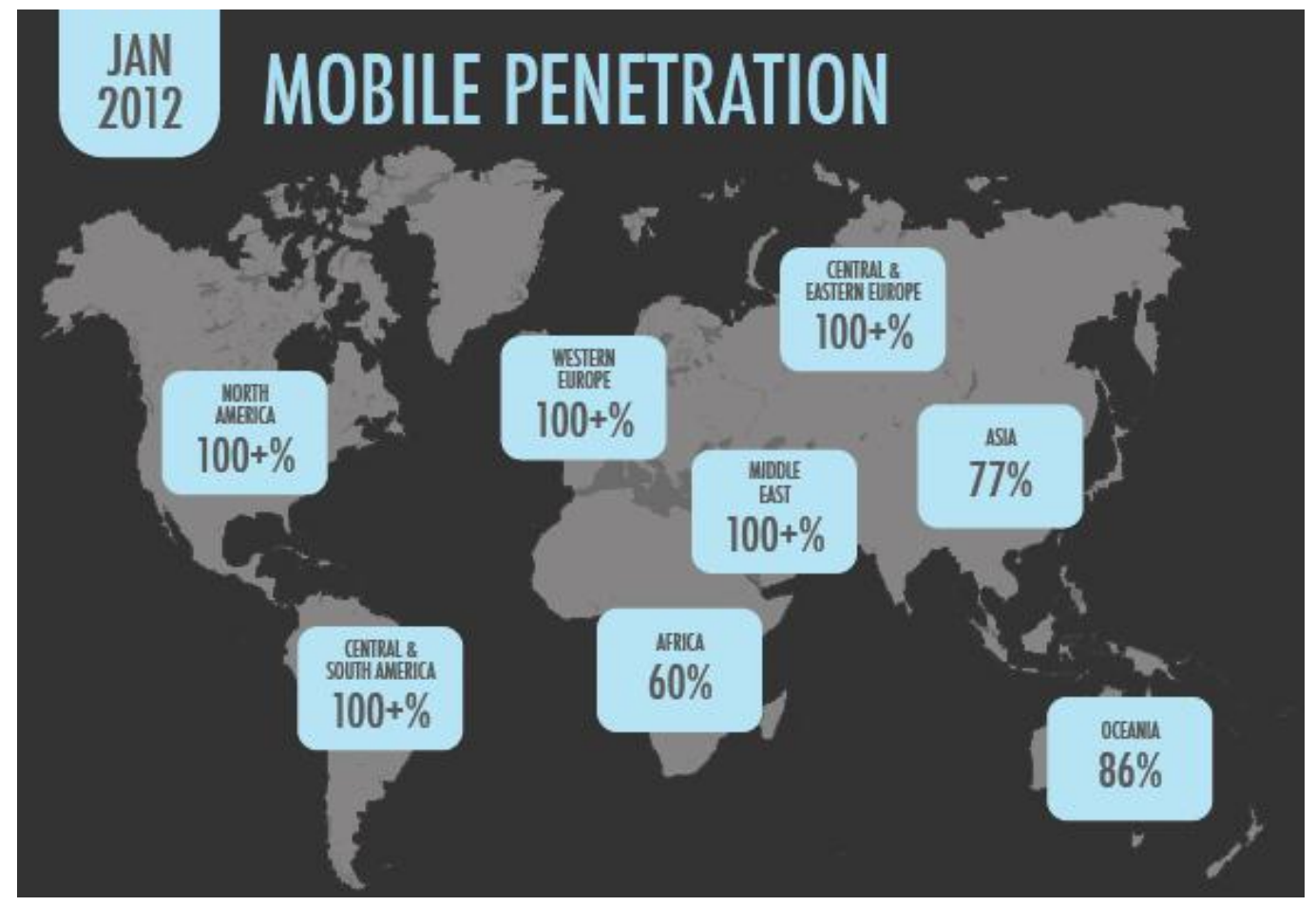

Source: Online Marketing Trends (n.d.). 
NOTES 